\title{
SPINE SCHOOL FOR PATIENTS WITH LOW BACK PAIN: INTERDISCIPLINARY APPROACH
}

\author{
ESCOLA DE COLUNA PARA PACIENTES COM LOMBALGIA: ABORDAGEM INTERDISCIPLINAR
}

\author{
ESCUELA DE COLUMNA PARA PACIENTES COM DOLOR LUMBAR: \\ ENFOQUE INTERDISCIPLINARIO
}

\begin{abstract}
Janaina Moreno Garcia ${ }^{1}$, Pola Maria Poli de Araújo¹, Maria Stella Peccin¹, Ricardo Edésio Amorim Santos Diniz²,
\end{abstract}
Roger Amorim Santos DinIZ², ImpérIo LOMBard JÚnIOR ${ }^{1}$

\begin{abstract}
Objective: To analyze and evaluate an interdisciplinary educational treatment - Spine School. Methods: This study is a non-controlled clinical trial. Twenty one individuals (19 women) aged 27-74 years diagnosed with chronic low back pain were enrolled and followed-up by a rheumatologist and an orthopedist. The evaluations used were SF36, Roland Morris, canadian occupational performance measure (COPM) and visual analogue scale (VAS) of pain that were performed before and after seven weeks of treatment. Results: We found statistically significant improvements in vitality (mean 48.10 vs. 81.25) $p=0.009$ and limitations caused by physical aspects (mean 48.81 vs. 81.25) $p=0.038$ and perception of pain (mean 6.88 vs. 5.38) $p=0.005$. Although the results were suggestive of improvement, there were no statistical significant differences in the domains social aspects (average 70.82 vs. 92.86) $p=0.078$, emotional aspects (average 52.38 vs. 88.95) $p=0.078$, and the performance satisfaction (mean 4.94 vs. 8.24) $\mathrm{p}=0.074$. Conclusion: The Interdisciplinary Spine School was useful for improvement in some domains of quality of life of people with low back pain.
\end{abstract}

Keywords: Low back pain; Quality of life; Employee performance appraisal; Education.

\section{RESUMO}

Objetivo: Analisar e avaliar um tratamento educativo interdisciplinar - Escola da Coluna. Métodos: Este estudo é um ensaio clínico não controlado. Participaram 21 indivíduos (19 mulheres) com idade de 27 a 74 anos, diagnosticados com lombalgia crônica e acompanhados por reumatologista e ortopedista. As avaliações usadas foram SF36, Roland Morris, medida canadense do desempenho ocupacional (COPM) e escala visual analógica (EVA) da Dor, que foram realizadas antes e após sete semanas de tratamento. Resultados: Obtivemos melhoras estatisticamente significantes na vitalidade (média 48,10 vs. 81,25), p=0,009 e nas limitações por aspectos físicos (média 48,81 vs. 81,25), $p=0,038$ e na percepção da dor (média 6,88 vs. 5,38), $p=0,005$. Embora os resultados tenham sido sugestivos de melhora, não houve diferenças estatísticas significantes nos domínios aspectos sociais (média 70,82 vs. 92,86), p=0,078, aspectos emocionais (média 52,38 vs. 88,95), $p=0,078$ e na satisfação com o desempenho (média 4,94 vs. 8,24), $p=0,074$. Conclusão: A Escola da Coluna interdisciplinar mostrou-se útil para melhora de alguns domínios da qualidade de vida de pessoas com lombalgia.

Descritores: Lombalgia; Qualidade de vida; Avaliação de desempenho profissional; Educação.

\section{RESUMEN}

Objetivo: Analizar y evaluar un tratamiento educativo interdisciplinario - Escuela de la Columna. Métodos: Este estudio es un ensayo clínico no controlado. Participaron 21 personas (19 mujeres) de edades de 27 a 74 años con diagnóstico de dolor lumbar crónico que fueron acompañadas por un reumatólogo y un ortopedista. Las evaluaciones utilizadas fueron SF36, Roland Morris, medida canadiense de rendimiento ocupacional (COPM) y la escala visual analógica (EVA) del dolor, que se llevó a cabo antes y después de siete semanas de tratamiento. Resultados: Se obtuvieron mejorías estadísticamente significativas en la vitalidad (promedio 48,10 vs. 81,25), $p=0,009$ y limitaciones debido a aspectos físicos (promedio 48,81 vs. 81,25) $p=0,038$ y la percepción del dolor (media 6,88 vs. 5,38) $p=0,005$. Aunque los resultados fueron indicativos de mejora, no hubo diferencias estadísticamente significativas en los dominios aspectos sociales (promedio 70,82 vs. 92,86) $p=0,078$, aspectos emocionales (promedio 52,38 vs. 88,95) $p=0,078$ y la satisfacción del rendimiento $(4,94$ vs. 8,24) p=0,074. Conclusión: La Escuela Interdisciplinaria de la Columna fue útil para la mejora en algunas áreas de la calidad de vida de las personas con dolor lumbar.

Descriptores: Dolor de la región lumbar; Calidad de vida; Evaluación del rendimiento de empleados; Educación.

\section{INTRODUCTION}

On average, between $65 \%$ and $80 \%$ of the world's population develops low back pain at some point in their lives, generating high costs associated with the treatment of low back pain, and of patients with chronic pain ${ }^{1}$

Low back pain has multifactorial causes; it can be exacerbated by factors such as age, gender, and low income, and females are more affected. $^{3}$
Some treatments for low back pain focus only on the physical aspects of the illness, but with the steady increase in complaints from individuals, the creation of different methods and means of treatment became necessary. One of these methods was the creation of the Spine/Posture School. ${ }^{4}$

The first Spine School emerged in 1969, in the Danbery Hospital in Sweden, and was called the Back School, ${ }^{5}$ an educational and training program for people diagnosed with chronic

\footnotetext{
1. Universidade Federal de São Paulo (UNIFESP), Campus Baixada Santista, Santos, SP, Brazil.
}

2. Universidade Metropolitana de Santos (UNIMES), Santos, SP, Brazil.

Study conducted at the Universidade Federal de São Paulo, Campus Baixada Santista, Santos, SP, Brazil.

Correspondence: Av. Ana Costa, 95. Vila Mathias, Santos, SP, Brazil. 11060-001. janaina_mgarcia@ rocketmail.com 
low back pain, focusing on its prevention and the promotion of spine health.

In Brazil, the first Back School, known as the "Escola de Postura" [Posture School], was introduced at the Hospital do Servidor Público Estadual de São Paulo6, São Paulo, SP, Brazil, in 1972.

Based on the diversity of populations, interventions, and comparison groups, there is insufficient information about the clinical effects of back schools, ${ }^{7}$ because many schools presented divergent results; in the American school there is evidence of improvements in pain and disability, while in Brazil, the best results relate to pain, functionality, and social issues ${ }^{5}$

Interdisciplinary follow-up enables the synthesis of knowledge from different scientific fields, and facilitates broader, biopsychosocial care. The Spine School therefore proposes this type of enhanced care.

This study evaluates the results obtained from the Interdisciplinary Spine School.

\section{MATERIAL AND METHODS}

This study was part of a university extension program, therefore no informed consent was signed. This was a non-controlled clinical trial. Twenty-one volunteers of both sexes, with symptomatic diagnoses of chronic low back pain, selected from an outpatient spine clinic, participated in The Spine School.

Volunteers with symptomatic diagnoses of non-specific chronic low back pain who were in regular medical follow-up were included in the study. Participants with cognitive deficits, determined by a score of less than 13 points in a mini mental state examination (MMSE), and who missed more than two treatment sessions, were excluded.

The volunteers were evaluated in relation the categories of pain, quality of life, function, and level of satisfaction with the treatment, at the beginning and at the end of the program. Meetings took place once a week, for one hour, over a total of seven weeks.

The evaluation tools used were:

1. Mini mental state examination (MMSE): this is a clinical assessment of changes in cognitive state (a process involving attention, perception, memory, reasoning, judgment, imagination, thinking, and language). The test attempts to evaluate temporal and spatial orientation, immediate memory, attention and calculation, evocation, language, and praxis, ${ }^{8}$ and is validated for Brazil, ${ }^{9}$ with the following cutoff scores: Illiterate: 13 points; Did not complete elementary school (years 1 to 8 ): 18 points; Completed elementary school or higher ( 8 or more years): 26 points. The maximum score is 30 points.

2. Visual analog scale for pain (VAS): assessment of pain at rest and in motion, varying from 0 (zero) for no pain to 10 (ten) for unbearable pain. ${ }^{10}$

3. SF-36 (The Short Form Health Survey): assessment of the quality of life, validated in Portuguese in 1999, consisting of eight sections: functional capacity, limitations from physical aspects, pain, general state of health, vitality, social aspects, emotional aspects, and mental health ranging from 0 (zero) to 100 (a hundred). The higher the score, the better the quality of life. ${ }^{11}$

4. Roland Morris, a questionnaire of 24 questions to evaluate the disability of patients with low back pain, translated into and validated for Portuguese. ${ }^{12}$

5. COPM (Canadian Occupational Performance Measurement) tool, capable of measuring the impact of an intervention of an individual and thus to detect changes in the client's self-perception in terms of their occupational performance and long term satisfaction, validated for Portuguese. ${ }^{13}$ First, patients must list the five activities that they find most difficult to perform on a day-to-day basis, and then score them from zero to ten, considering their performance and their satisfaction with the final results of the task. The score ranges from 0 to 10 , with a higher score indicated better performance ability.

6. The meetings/classes took place as follows: 1) Initial evaluation to assess demographic data, application of MMSE, VAS, SF-36,
Roland Morris, and COPM tools and anatomy classes; 3) Class on diseases of the spine; 4) Types and the importance of medical diagnosis and treatment; 5) Physical exercises to strengthen the abdominal musculature, for lumbar stretching, and breathing control; 6) Theoretical and practical orientation on joint protection in performing daily activities, with the use adaptations to furniture and household utensils, where necessary; and 7) Nutritional counseling.

The data were expressed as averages and standard deviations. The Student-t test was used to compare the results obtained in the evaluation and reevaluation.

\section{RESULTS}

Twenty-one volunteers took part in the program, ranging from 27 to 74 years of age (average of 57.611 years of age). (Table 1)

In our study, we observed that the initial and final evaluations showed significant improvements in vitality, limitations from physical aspects, and pain intensity, demonstrating that the theoretical and practical classes in postural counseling, environmental adaptations, and strengthening, stretching, and relaxation exercises achieved the desired outcomes in terms of awareness and changes to some daily activities. The SF-36 results suggested improvements in the domains of social aspects, emotional aspects, and satisfaction with performance, but without significant differences. (Table 2)

We obtained statistically significant differences in vitality (average 48.10 vs. 81.25, $p=0.009$ ), in limitations from physical aspects (average $48.81 \mathrm{vs} .81 .25, p=0.038$ ), and in the perception of pain (average 6.88 vs. 5.38, $p=0.005$ ), and while the results suggested an improvement, there were no statistically significant differences in the domains of social aspects (average 70.82 vs. 92.86, $p=0.078$ ), emotional aspects (average 52.38 vs. 88.95, $p=0.078$, or satisfaction with performance (average 4.94 vs. 8.24, $p=0.074$ ).

Table 1. Characteristic of the study population by sex and average age.

\begin{tabular}{c|c|c|c}
\hline Sex & Male & Female & Total \\
\hline Number of individuals & 2 & 19 & 21 \\
\hline Age (years) & $58(7.07)$ & $57.57(13.19)$ & $57.61(12.61)$
\end{tabular}

Data expressed as averages (standard deviation).

Table 2. Results obtained from the SF-36 quality of life, Roland Morris, and COPM (Canadian Occupational Performance Measurement) questionnaires.

\begin{tabular}{l|c|c|c}
\hline \multicolumn{1}{c|}{ Variable } & Pre-Intervention & Post- Intervention & p \\
\hline \multicolumn{1}{c|}{ SF36 } & & & \\
\hline 1. Functional capacity & $60.71(28.56)$ & $66.25(32.04)$ & 0.245 \\
\hline 2. Limitations from physical aspects & $48.81(40.68)$ & $81.25(37.20)$ & 0.038 \\
\hline 3. Pain & $47.62(22.14)$ & $68.25(18.52)$ & 0.198 \\
\hline 4. General state of health & $64.95(23.44)$ & $72.14(32.08)$ & 0.361 \\
\hline 5. Vitality & $48.10(20.09)$ & $67.14(16.80)$ & 0.009 \\
\hline 6. Limitations from social aspects & $70.82(30.19)$ & $92.86(14.17)$ & 0.078 \\
\hline 7. Limitations from emotional aspects & $52.38(46.63)$ & $88.95(32.53)$ & 0.078 \\
\hline 8. Mental health & $66.29(22.89)$ & $77.14(14.37)$ & 0.118 \\
\hline Canadian Measurement - COPM & & & \\
\hline 1. Performance & $5.03(2.97)$ & $7.62(1.06)$ & 0.150 \\
\hline 2. Satisfaction & $4.94(3.09)$ & $8.24(1.54)$ & 0.074 \\
\hline \multicolumn{1}{c|}{ Roland-Morris } & $9.95(6.25)$ & $6.88(6.20)$ & 0.363 \\
\hline Visual Analog Scale for Pain - VAS & $6.88(1.25)$ & $5.38(1.19)$ & 0.005 \\
\hline
\end{tabular}

Data expressed as averages (standard deviation). 


\section{DISCUSSION}

Our study showed that patients with chronic low back pain who participated in the spine school follow-up achieved improvements through a reduced perception of pain and in some areas of the quality of life questionnaire, such as vitality and limitations from physical aspects, with the suggestion of improvement in emotional and social aspects and satisfaction with occupational performance.

The inter/multidisciplinary interventions for the treatment and physical rehabilitation of chronic low back pain showed promising results, ${ }^{7}$ because, as an approach which combines various types of knowledge, it favors integrated care of the patient's health.

Unlike Van Middelkoop et al, ${ }^{7}$ who state that they did not find statistically significant short term improvements in their studies, our program produced good results over a short period of time, which may be explained by the low number of participants in the classes, favoring total attention to each participant, the presence of different professionals running the classes, and the approach that was focused on the interests of each participant.

According to Chung, ${ }^{5}$ the Spine School program is efficient, mainly in making the patient aware that he is the key agent for promoting his own health, and because it is a multi/interdisciplinary program that provides different perspectives on the same problem by different health professionals, with the aim of improving the participant's overall health.

With the use of the Canadian Occupational Performance Measurement (COPM), although no significant statistically significant differences were observed, an improvement in the participants is indicated, as changes in self-perception, occupational performan$c e$, and satisfaction were observed during their participation in our educational program.

The SF-36 assessment of the quality of life suggests that the interdisciplinary Spine School positively influenced the lives of the volunteers who, although still living with the disease, looked for ways to improve their physical, emotional, psychological, and social health.

The rate of Spine School educational program participant dro- pouts is widely reported in the literature,${ }^{14}$ making constant redesign of these treatments necessary. In our program we tried to be as flexible as possible and to adapt class schedules to accommodate the demands of the volunteers.

The first limitation of our study is the number of volunteers. There was a high dropout rate over the seven-week class period, indicating the need to rethink the form of patient contact, seeking to adapt class schedules to better accommodate their availability, since our Interdisciplinary Spine School program is the only one in the region.

Many of the participants in our program are from other municipalities and have low incomes, which can make access to the location where classes were held more difficult. Often, patients had to miss work or travel long distances.

We understand the importance of following the CONSORT guidelines for clinical trials, but because this research was part of a pioneer project in the region, we had difficulty selecting volunteers. For this reason, we opted not to use a control group, or any of the other items required for stricter methodological control.

More research is needed on the efficacy of spine schools ${ }^{15}$ because many of the findings in the literature are conflicting, and present little evidence of their effectiveness, generating doubts as to the effectiveness of this type of treatment. In future research, the number of participants should be increased and a control group included to enable a controlled and randomized clinical trial to be conducted.

\section{CONCLUSION}

We conclude that in this Interdisciplinary Spine School, we obtained significant improvement in the perception of pain and in the areas vitality and physical aspects, and an indication of improvement in the emotional and social aspects and satisfaction with performance in patients with chronic non-specific low back pain.

All authors declare no potential conflict of interest concerning this article.

\section{REFERENCES}

1. Borenstein DG. Epidemiology, etiology, diagnostic evaluation, and treatment of low back pain. Curr Opin Rheumatol. 2000;12(2):143-9.

2. Ouédraogo DD, Ouédraogo V, Ouéfraogo LT. Prevalência e fatores associados à dor lombar entre os funcionários do hospital, em Ouagadougou (Burkina Faso). Med Tropicale. 2010;70(3):277-80

3. Shiri R, Karppinen J, Leino-Arjas P, Solovieva S, Viikari-Juntura E. The association between obesity and low back pain: a meta-analysis. Am J Epidemiol. $2010 ; 171(2): 135-54$.

4. Helfenstein Junior M, Goldenfum MA, Siena C. Occupational low back pain. Rev Assoc Med Bras. 2010:56(5):583-9.

5. Chung TM. Escola de Coluna: experiência do Hospital das Clínicas da Universidade de São Paulo. Acta Fisiátr. 1996;3(2):13-7.

6. Andrade SC, Araújo AGR, Villar MJP. "Escola de coluna": revisão histórica e sua aplicação na lombalgia crônica. Rev Bras Reumatol. 2005:45(4):224-8.

7. van Middelkoop M, Rubinstein SM, Kuijpers T, Verhagen AP, Ostelo R, Koes BW, et al. A systematic review on the effectiveness of physical and rehabilitation interventions for chronic non-specific low back pain. Eur Spine J. 2011;20(1):19-39.

8. Folstein MF, Folstein SE, McHugh PR. "Mini-mental state." A practical method for grading the cognitive state of patients for the clinician. J Psychiatr Res. 1975;12(3):189-98.
9. Bertolucci PH, Brucki SM, Campacci SR, Juliano Y. The Mini-Mental State Examination in a general population: impact of educational status. Arq Neuropsiquiatr. 1994;52(1):1-7

10. Huskisson EC, Jones J, Scott PJ. Application of visual-analogue scales to the measurement of functional capacity. Rheumatol Rehabil. 1976;15(3):185-7.

11. Ciconelli RM, Ferraz MB, Santos WS, Meinão IM, Quaresma MR. Tradução para a língua portuguesa e validação do questionário genérico de avaliação de qualidade de vida SF36 (Brasil SF36). Rev Bras Reumatol. 1999;39(3):143-50.

12. Nusbaum L, Natour J, Ferraz MB, Goldenberg J. Translation, adaptation and validation of the Roland-Morris questionnaire--Brazil Roland-Morris. Braz J Med Biol Res. 2001;34(2):203-10.

13. Magalhães C, Magalhães LV, Cardoso AA. Medida canadense do desempenho ocupacional - COPM. Versão Traduzida e validada. Belo Horizonte: Editora UFMG.; 2009

14. Tsukimoto G.R. Avaliação longitudinal da escola de postura para dor lombar crônica através da aplicação dos questionários Roland-Morrise Short Form Health Survey (SF36) [dissertação]. São Paulo: Faculdade de Medicina, Universidade de São Paulo; 2006.

15. Brox JI, Storheim K, Grotle M, Tveito TH, Indahl A, Eriksen HR. Systematic review of back schools, brief education, and fear-avoidance training for chronic low back pain. Spine J. 2008;8(6):948-58. 